\title{
Europe's 2020 vision
}

\section{With new climate and energy legislation, the EU aims to stride boldly ahead of its previous climate policies while protecting its economy from less-green competitors. Anna Barnett reports.}

$\mathrm{N}$ ew climate and energy legislation proposed by the European Commission in January will be discussed by EU heads of state in Brussels March 13-14 before the European Parliament takes it up for debate.

The proposal aims to reduce Europe's carbon dioxide emissions to $20 \%$ below 1990 levels by 2020 and will increase the cut to $30 \%$ if a global climate deal is reached in international negotiations. It also calls for the EU to use $20 \%$ renewable energy, including $10 \%$ biofuel for transport, by 2020. EU governments agreed in March 2007 to pursue the '20 20' policy, and January's draft bill is the most concrete step yet toward their goals.

Those goals disappoint many green groups, however. Though a $20 \%$ emissions cut is far above previous Kyoto Protocol targets, it falls below the cut of $25-40 \%$ from 1990 levels by 2020 envisioned at a UN conference in Vienna last August, based on recommendations of the Intergovernmental Panel on Climate Change (IPCC). The EU pushed the $25-40 \%$ benchmark at December's UN Climate Change Conference in Bali, Indonesia, but opponents led by the US kept those numbers out of the Bali agreement. Many climate scientists maintain that nothing less will prevent dangerous climate change. The prescription of $10 \%$ biofuels has also raised questions, given concerns that production of certain types of biofuels could increase net greenhouse gas emissions and contribute to ecological and humanitarian crises.

But some business leaders believe the proposed regulations go too far. The envisioned carbon cuts are to be achieved largely through strengthening of the EU Emissions Trading System

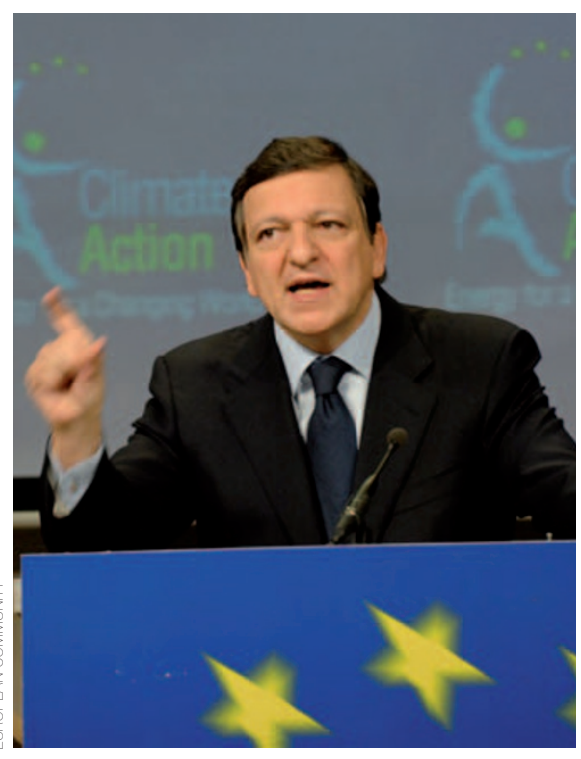

European Commission President José Manuel Barroso at a press conference 23 January.

(ETS), the world's largest scheme for trading carbon, from 2013. In the current ETS, each country doles out free carbon dioxide emissions permits to several high-emissions industries, and the greenest businesses can sell permits to the bigger polluters. The new plan sets emissions allowances across Europe, ending nation-by-nation apportioning, and limits the greenhouse gases nitrous oxide and perfluorocarbons as well as carbon dioxide.

More controversially, the plan brings additional industries such as steel, chemical and aluminium manufacturing into the scheme and calls for many permits to be sold at auction from 2013. Starting then, power plants would have to buy all their permits, preventing the alleged profiteering seen in earlier phases of the ETS. Manufacturers - who, unlike the power sector, face competition from countries without emissions limits - would also have to contend with costly permits. Finance ministers agree with industry that if only European factories must pay to emit, jobs will be uselessly sacrificed as polluters simply move overseas.

To stave off this threat, the European Commission's proposal delays until 2010-2011 the decision on how many manufacturing permits to auction. And EU environment minister Stavros Ditmas has said that if big competitors like the US, China and India haven't signed on to mandatory emissions cuts by 2011, the EU might protect its economy - and apply leverage on the climate question - by forcing importers to buy emissions permits. The US says it will resist any such tariff.

A final version of the new legislation, which must yet be agreed by the European Parliament and ministers from the $27 \mathrm{EU}$ governments, could be approved in December 2008, allowing for implementation to begin late in 2009 . By then, the EU's firm stand may help attract support for aggressive emissions targets in an international climate deal. But if Europe fails to press the rest of world to action, the new EU directives alone will do little to stabilize greenhouse gases at safe levels globally in the coming century.

\section{Published online: 28 February 2008.}

doi:10.1038/climate.2008.19

Anna Barnett is assistant editor and copy editor of Nature Reports Climate Change. 